\title{
Majority, grand or all-party coalitions?
}

\author{
Peter Emerson \\ The de Borda Institute, 36 Ballysillan Road, Belfast BT14 7QQ, Northern Ireland \\ E-mail address: pemerson@deborda.org
}

\begin{abstract}
By what principle does one majority have the right to rule, and another not? Secondly, while elections are generally transparent, why should forming a government be secretive? Is it because people believe, not only in majority rule, which may be fine, but also in (simple or weighted) majority voting, which is not so good? There are, after all, other more accurate voting systems by which can be identified the will of the majority; some of these latter methodologies are non-majoritarian. Now, if decision-making were to be based on a non-majoritarian voting procedure, the right to majority rule might be brought into question; indeed, majoritarianism might become obsolescent. Other forms of governance should therefore also be examined. Accordingly, this paper considers first, some of the deficiencies of a majoritarian polity; next, a more inclusive form of decision-making; then, majoritarian and non-majoritarian types of governance; and lastly, a voting system by which a parliament may elect a national government.
\end{abstract}

Keywords: Consensus; consensors; modified Borda count (MBC); power-sharing; all-party coalition; matrix vote

\begin{tabular}{|c|c|c|}
\hline \multicolumn{3}{|c|}{ Abbreviations } \\
\hline AGM & & annual general meeting \\
\hline $\mathrm{AV}$ & $=\mathrm{IRV}=\mathrm{PV}=\mathrm{STV}$ & alternative vote \\
\hline $\mathrm{BC}$ & & Borda count \\
\hline CDU & (Germany) & Christian Democratic Union (Christlich Demokratische Union) \\
\hline $\mathrm{CSU}$ & (Germany) & Christian Social Union (Christlich-Soziale Union) \\
\hline DRC & & Democratic Republic of the Congo \\
\hline EEC & & European Economic Community \\
\hline EU & & European Union \\
\hline FDP & (Germany) & Free Democratic Party (Freie Demokratische Partei) \\
\hline FPP & & first-past-the-post \\
\hline GNU & & government of national unity \\
\hline IRV & $=\mathrm{AV}=\mathrm{PV}=\mathrm{STV}$ & instant run-off voting \\
\hline MBC & & modified BC \\
\hline
\end{tabular}




\begin{tabular}{|c|c|c|}
\hline \multicolumn{2}{|l|}{ MMP } & multi-member proportional \\
\hline \multicolumn{2}{|l|}{ MP } & member of parliament \\
\hline \multicolumn{2}{|r|}{ (Poland) } & Law and Justice (Prawo i Sprawiedliwość) \\
\hline \multicolumn{2}{|l|}{ PR } & proportional representation \\
\hline \multicolumn{2}{|c|}{ PR-STV } & PR - single transferable vote \\
\hline \multicolumn{2}{|r|}{ (Poland) } & Polish People's Party (Polskie Stronnictwo Ludowe) \\
\hline \multicolumn{3}{|c|}{ Australasia) } \\
\hline QBS & & quota Borda system \\
\hline SPD & (Germany) & Social-democratic Party (Sozialdemokratische Partei Deutschlands) \\
\hline STV & $=\mathrm{AV}=\mathrm{IRV}=\mathrm{PV}$ & single transferable vote \\
\hline TRS & & two-round system \\
\hline
\end{tabular}

\section{INTRODUCTION}

In 2013, Germany took five weeks to form a government. The process involved several inter-party talks and one all-night session, i.e., not a lot of transparency. Other nations have suffered rather more from similar periods of uncertainty. Iraq, for example, which in 2010 could ill afford such behaviour, took 249 days. Shortly afterwards, Belgium, where at least there was no bloodshed, took 541. There must be a better way.

In a two-party system, as in the UK, the usual practice is for the larger party to form the government while the smaller remains in opposition; it is all very adversarial. In a more plural democracy, as in Poland, the mathematics of forming a similarly adversarial governmentversus-opposition structure often offers more than one possibility. So by what dogma does one majority have the right to rule, and another not? Or, to put it another way, by what right may a small party be included in government while another larger party is excluded? Or maybe a more fundamental question should be asked: could a more inclusive polity be considered? Many people believe in majority rule - which, in so far as it goes, is adequate. On this basis, they also believe in, or at least practice, majority voting - but this is not a good way of identifying the majority opinion. Indeed, as shall be seen in a moment, a majority opinion (can be ratified, perhaps, but) cannot be identified by a majority vote. For reasons various, however, majority voting is all but ubiquitous - in politics, in law, in business and in civic society. The vote may be simple or weighted, qualified (as in the EU), twin (as in some Swiss referendums) ${ }^{1}$ or consociational (as in Belgium and Northern Ireland, for example); it may be initiated by the powers that be or, as in a citizens' initiative, by the general public; and it might have an additional proviso, as in a constructive vote of no confidence in the German parliament. ${ }^{2}$ Generally speaking, however, in spheres both political and apolitical, most users think that one or other form of majority voting may suffice and that, ipso facto, other voting

$1 \quad$ To succeed, a policy option may need both a majority of voters and a majority of the cantons.

2 Those wishing to vote against the current government must first present an alternative administration. 
procedures need not be considered. As a consequence, questions are usually dichotomous, debates become polarised, votes are divisive - in England's parliament, they are actually called divisions - and politics is adversarial. This practice of majoritarianism is seldom questioned. Indeed, there is a "surprisingly strong and persistent trend in political science to equate democracy solely with majoritarian democracy and to fail to recognise consensus democracy as an alternative and equally legitimate type."3 [1] Little wonder, then, that in Germany for example, many lawyers and political scientists see little contradiction in the fact that, while Art. 38 of the Basic Law talks of how the members of the Bundestag shall "be representatives of the whole people," Art. 42 stipulates that "Decisions of the Bundestag shall require [only] a majority of the votes cast." \{Arts. 38 (1) and 42 (2).\} A second contradiction concerns referendums. Given the abuse - or was it just use? - to which Hitler put this type of ballot, national polls are no longer allowe but referendums are permitted in the Länder where again a "majority" is required, \{Art. 29 (3)..

Germany is not alone. The Irish Constitution, Bunreacht na hÉireann demands that the rulers of the State shall "decide all questions of national policy, according to the requirements of the common good," (Art. 6.1), and yet questions in Dáil Éireann, the parliament, "shall be determined by [only] a majority of the votes" and similarly referendums shall be subject to "a majority of the votes cast," (Arts. 6.1, 15.11 and 47.1). Majoritarianism, it seems, at least in the West, is an idée fixe: "Democracy is based on majority decision."4 There are, however, some other voting methodologies, a few are multi-optional, a couple are non-majoritarian, and when these procedures are compared to (simple or weighted) majority voting, the latter is seen to be a very inaccurate measure of collective opinion. If majority voting were put under scrutiny, and if, as a result, decision-making in the future were to be based on a more sophisticated voting procedure, the right to majority rule by majority vote - majoritarianism might be brought into question; and so too, therefore, the very concept of majority and/or grand coalitions. Furthermore, if the accepted form of democratic decision-making were to be non-majoritarian, that right would definitely need to be challenged. So maybe it is time to consider, not only the more sophisticated methodologies of decision-making, but also majoritarianism. Accordingly, this paper examines, firstly, contemporary majoritarian democratic structures; secondly, the nature of an inclusive voting procedure for decisionmaking; thirdly, majoritarian governance and other possibilities; and finally, a voting procedure by which a parliament may elect a government of national unity, GNU.

\section{MAJORITY RULE}

It was long since realised that minority rule was wrong, and often horribly so. Its natural opposite, majority rule, seemed to be the obvious alternative, and it was generally accepted that, in the absence of unanimity, the opinion of the majority should hold sway. The question, therefore, was this: how should that majority opinion be identified? or can a majority opinion be identified by a majority vote? Paradoxical though it may sound, the answer is no.

A majority opinion can be ratified, perhaps, if, via extensive consultations (or clever guess work), those choosing the one (or two) ballot paper option(s) have managed to identify

\footnotetext{
3 Lijphart is here talking of a consociational democracy, which is still dichotomous; a consensus democracy would best be based, inter alia, on multi-option decision-making.

4 International UNESCO Education Server for Civic, Peace and Human Rights Education, http://www.dadalos.org/int/Demokratie/Demokratie/Grundkurs5/mehrheitsprinzip.htm (accessed 22.1.2014).
} 
that opinion in advance. In a small forum, such as the UN Security Council where only 15 member states are involved and where all-inclusive dialogues are feasible, it might be possible to identify such an opinion by means of much discussion and then a binary ballot but see below. In a parliament of over 100, however, let alone in a nation of millions, it is probably impossible. This is not least because, as in any ratification process, the said opinion must be identified earlier if it is to be already on the ballot paper.

Majority voting has other disadvantages. The identification of 'the will of the people' cannot be facilitated if, as part of that process, many of those concerned do not identify their individual wills, i.e., if they vote only 'no', if they do not say what they want but only what they don't want. Accordingly, any ballot should consist of two (or more, as shall be seen in a moment) positive questions. France's 2005 referendum on the Lisbon treaty, for example, was a straight 'oui ou non?' Those in favour of the EU and the treaty said 'oui'; but those who voted 'non' included, not only those who did not like the treaty, but also those who disagreed with the EU per se, and/or the prospect of Turkish accession, and/or the spread of McDonalds restaurants, and/or the policies of Jacques Chirac, and/or je ne sais qois! At the very least, the question should have been: "Do you want the UE to be comme ci, with the treaty, or comme ça, without?"

Other rather more serious situations also failed to identify the true 'will of the people', again because so many individuals did not express a positive opinion about the problem under discussion. For many years during the Northern Ireland 'troubles' as they were called, no matter what the question, "Ulster said "no!" Similar situations were seen in Republika Srpska, where 96 per cent said 'no' to the Vance-Owen plan in 1993; in Gibraltar where 99 per cent did not want to share sovereignty; and in Cyprus where 76 per cent of Greek Cypriots and 35 per cent of Turkish Cypriots were equally negative about Kofi Annan's re-unification plan. The result of such polls, what those concerned did not want, was then common knowledge; but what they actually wanted, the exact will of the people, was still unknown.

In other troubled jurisdictions, even overwhelmingly positive votes can be somewhat meaningless. In Kosovo in 1991, 99 per cent voted for independence; but doubtless a (slightly smaller but still large) majority would also have voted positively if the question had suggested unification with Albania or even a greater Albania. In like manner, over 99 per cent of the Falklands/Malvinas voted to stay as an Overseas Territory of the UK in 2013, but any other status, as long as it was British, would probably have received a similarly large endorsement.

A third disadvantage of majority voting relates to the fact that in most of the above ballots and in many plebiscites on independence - those in the Balkans and the Caucasus, for example - the two-option question by its very nature disenfranchises not only those who were parents in and/or children of a mixed marriage, but also those who might otherwise want to vote for compromise. It is at least sad to note that, in the Balkans, the EU (or EEC as it was then called) was partly responsible: its Badinter Commission, a team of five presidents of national constitutional courts, recommended the use of the two-option plebiscite. On reflection, to quote Sarajevo's now legendary newspaper, "all the wars in the former Yugoslavia started with a referendum," (Oslobodjenje, 7.2.1999).

Fourthly, majority voting can be very capricious. Indeed, on some occasions, the vote can be swayed by the vacillation of just a few voters or even by that of only one person. In a hung parliament, the latter may be bribed, seduced or whatever, but the result is a complete reversal of what would otherwise have been the case. Several incidents of this nature may be found in Won by One, http://www.deborda.org/won-by-one/ (accessed 23.2.2014).

A fifth disadvantage is as follows: in contemporary society, where many a democracy aspires to the adjective 'plural', there are lots of instances where a final policy choice is best 
not reduced to a dichotomy, or even a series of such binary votes. In choosing the venue for the 2012 Olympics, for example, when the short list consisted of five options - London, Madrid, Moscow, New York and Paris - any two-option vote on, say, Madrid v Paris, could have been pretty meaningless, not least because the outcome could well have been decided by tactical voters in favour of neither. In 1996, Slovenia held a three-option debate on its electoral system, took three majority votes and lost them all. Seven years later, the British House of Lords had a five-option debate on Lords reform, took five majority votes, and again, lost the lot. Slovenia subsequently decided that the option with the largest minority should be the outcome; Westminster decided not to make a decision at all and instead to continue arguing. Interestingly enough, Lord Meghnad Desai had actually called for a Borda count, BC, Hansard, 22.1.2003); ${ }^{5}$ but no, democracy, after all, or so they said (and still say), must be based on a decision by a majority. Subsequent to that and a similar fiasco in the Commons, the late Robin Cook MP tried to introduce a form of preference votin in vain; for "that would have involved," he later bemoaned, "the technological development of a pencil and a piece of paper, which was far too big a step for our parliament and its medieval procedures."6

It might also be noted that, even on those occasions where there are definitely only two options - as in the question, 'Which side of the road shall we drive on?' - there may be more than two ways of voting, ${ }^{7}$ so to cater, perhaps, for those who were totally committed to the democratic process but who, on this particular issue, were indifferent.

As noted above, for-or-against binary voting is ubiquitous. When the UN Security Council debated Iraq in 2002, there was only one resolution on the table and, yet again, the vote was simply 'yes-or-no'. The debate among the 15 participants should have facilitated the identification of the common ground; but it did not. Hence the ridiculous situation in which France and Germany both voted in favour of something they did not like. ${ }^{8}$ Perhaps, they felt that Resolution 1441 was better than nothing, or maybe that other factors like the need for international solidarity held sway. Given such interpretations, however, it would be quite wrong to conclude, as was said at the time, that the policy had unanimous support.

In many forums and on many occasions, a majority vote ballot cannot include the full list of options available. This means, of course, that some voters cannot express their views accurately. In which case, any outcome which is based on an analysis of such inaccurate facts may itself be inaccurate. This is the eighth disadvantage.

In practice, then, a majority vote often identifies, with certainty, not the 'will of the people', not even the will of the majority, but only the will of those who wrote the question. Not for this reason alone, the two-option (simple or weighted) majority vote has often been the chosen instrument of a dictator. As referred to in the introduction, Hitler used a simple

\footnotetext{
5 He did not use the term, 'Borda count', but the voting mechanism he described was indeed a BC.

6 Taken from an interview with Alexandra Runswick, which was published by Unlock Democracy in Spring, 2005:

http://www.unlockdemocracy.org.uk/wp-content/uploads/2007/01/2-robin-cook.pdf (Accessed 4.10.2012.) He did not specify which type of preference voting he would have advocated. It would appear that he wanted, initially, to get acceptance for the principle; and later debates could focus on the detail.

7 In Sweden's referendum on this question, there were three options on the ballot paper: 'left', 'right' and 'blank'.

$8 \quad$ Article 13 of the resolution, 'Recalls... that the Council has repeatedly warned Iraq that it will face serious consequences as a result of its continued violations of its obligations.' Both France and Germany objected to the words shown here in italics.
} 
majority vote in two referendums and a weighted majority vote in the infamous Enabling Act of 1933.

He was not alone, of course. Napoleon started the trend in 1800 and, in a series of three referendums, with at least 99 per cent support in all three, managed to become first consul, then consul for life, and finally emperor. It could be said (tongue in cheek) that to dictate properly, 100 per cent support would be necessary, and this was achieved in Chile in 1818 when an Irishman, Bernardo O'Higgins, became 'el supremo'. At a 1903 meeting of the AllRussian Congress of Social Democrats held initially in Brussels but later in London, Lenin won a majority by "the accidental arithmetic of a single ballot" - 19 'for', 17 'against' and three abstentions - [2]; hence the split into Bolsheviks and Mensheviks, and hence too the horrid history of the 1917 revolution and all that followed: but the very word 'bolshevik' means 'member of the majority'. ${ }^{9}$ Other dictators who have used majority voting, in party congress, parliament or referendum, include Mussolini, Duvalier, Gaddafi and Khomeini; the list is quite long, [3]. Furthermore, other autocrats have also based their policies on majoritarianism: “...the system of democratic centralism, in which the minority is subordinate to the majority..." was how Máo Zédōng put it in a speech in 1942, [4]. It is also salutary to recall that, in Rwanda, when the Interahamwe launched their ferocious genocide in 1994, the slogan they used was "rubanda nyamwinshi", 'we are the majority', [5].

In a word, be it in a referendum and/or in many a parliamentary majority vote, the twooption majority vote is indeed a "blunt" instrument, [6].

\subsection{Other forms of decision-making}

It is not only the dictators, of course, who have been tempted to manipulate decisionmaking. Indeed, apart from the 2002 vote in the UN Security Council mentioned above, there have been countless other instances where the government of the day has got its way, not least by using a majority vote: it writes the question, it has a majority in parliament, and so, all but inevitably, it wins. All too often, the question is the answer.

Only occasionally have parliaments resorted to a multi-option vote. Finland and Sweden sometimes use serial voting - a series of majority votes - when debating amendments; and Norway used a two-round system, TRS, in 1972, but one option won an outright majority in the first round, so really it was just a plurality vote. Multi-option voting has more frequently been used in referendums. New Zealand held the first, a three-option ballot on prohibition, in 1894; and in 1992, under a variation of TRS, a government appointed independent Commission initiated a five-option ballot on the electoral system. Guam used a more conventional form of TRS in 1982 in a constitutional referendum in which there were six options on the ballot paper and, just in case someone(s) wanted another arrangement, a seventh option was left blank for the voter(s) to specify. Elsewhere too - in Australia, Finland, Sweden and Uruguay, for example - there have been multi-option ballots varying from three to five options. [7].

One further multi-option ballot is worth a mention, if but because the methodology is non-majoritarian. In 2013, Dublin City Council wanted to choose a name for a bridge being built in the city centre. There were over eighty possibilities on the agenda. A sub-committee reduced this to ten, and then used $\mathrm{BC}$ to reduce it further to a short list of five options; later,

\footnotetext{
9 It comes from the Russian word for majority, 'bolshinstvo'. Similarly, the Menshevik is a member of the minority, 'menshinstvo'. In fact, of course, as the 1917 election showed, both the Bolsheviks and the Mensheviks were minorities, and the true majority was held by the Social Revolutionaries, (SRs): the Bolsheviks won 175 seats, the Mensheviks only 16, but the SRs won an outright majority of the 707 seats with a total of 370 .
} 
in a plenary session of the Council, another $\mathrm{BC}$ was used to identify the social choice, the final decision. $^{10}$

\section{INCLUSIVE DECISION-MAKING}

In those instances where there are more than two options 'on the table' there are many ways of voting. With the (perhaps approximate) year of its invention written in brackets, they include:

(i) plurality voting, (AD 105), in which the voter may cast only a single preference;

(ii) TRS, (1870), ${ }^{11}$ where the voter again casts just a single preference, if not once in a plurality vote, then again in a second ballot, a majority vote on the two leading options;

(iii) the alternative vote, $\mathrm{AV},{ }^{12}(1855)$, where the voter may cast up to as many preferences as there are options; in effect, an AV count is like a series of plurality votes, each round eliminating the least popular option and transferring the latter's votes according to the respective voters' second and subsequent preferences, until one option gets 50 per cent support;

(iv) in approval voting, (1268), the voter may 'approve' of one or some (but not all) ${ }^{13}$ options, and the option with the most 'approvals' is the winner;

(v) in a BC, (1435), or modified BC, MBC, to give it its full name, ${ }^{14}$ [8], the voter may cast his/her preferences on one, some or all of the options listed; preferences cast are turned into points, and the winner is the option with the most; finally,

(vi) in a Condorcet count, (1299), voters may again cast one, some or all of their preferences; in the count, pairs of options are considered as it were separately, and the option (if any) which wins the most pairings is the winner.

Uniquely, only the last two methodologies take every preference cast by every voter into account. Not for this reason alone, they are the two most accurate voting systems and, on many occasions, with many voters' profiles, the $\mathrm{MBC}$ and Condorcet social choice outcomes are the same, and sometimes too the two social rankings. The former is non-majoritarian so, for reasons outlined below, it is the recommendation of this paper. Although not then known by its current name, it was first devised in 1435 by Nicholas Cusanus, who said on reflection - and, as already implied, with the exception of $\mathrm{AV}$, all the voting procedures mentioned

\footnotetext{
10 This was reported in the press - http://www.thejournal.ie/dublin-city-marlborough-street-bridge1065818-Sep2013/ (accessed 10.12.2013) - and later analysed: http://www.deborda.org/home/2013/9/6/dublincity-council-a-record.html (accessed 5.1.2014).

11 The origin is uncertain, but TRS was used in Germany from 1870 - 1913 and in France from the revolution. Furthermore, multi-round voting was a feature in papal elections and those of the Venetian Doges.

12 Also known as instant run-off voting, IRV; preference voting, PV; and single transferable vote, STV; in the Americas, Australia and the UK respectively.

13 He who 'approves' of every option, in effect, wastes his vote.

14 In an MBC of $n$ options, the voter may cast $m$ preferences, where $n \geq m \geq 1$. Points are awarded to $\left(1^{\text {st }}\right.$, $2^{\text {nd }} \ldots$ last $)$ preferences cast according to the rule $(m, m-1 \ldots 1)$.
} 
above had been devised by this time - "Believe me, no more perfect system can be found." [9]. ${ }^{15}$ The same holds true today, for "the Borda count is significantly more consistent" than other voting procedures, [10].

\section{1. The MBC debate}

As in the UN Security Council, so too in any parliament, council, company board meeting, AGM, or whatever, every contentious debate should cater for a plurality of options. In any setting and most certainly in any political forum, a team of, say, three consensors - three elected but non-voting members of the judiciary - should adjudicate on which options comply with an agreed norm like the UN Charter on Human Rights, and then draw up and maintain a short list of options currently 'on the table' as well as, perhaps, on a dedicated website and, if need be in summary, on a computer screen.

In the debate itself, questions may be asked, clarifications sought, amendments suggested, composites proposed, and so on. If at the end of the day, there is but one option on the consensors' list, this may be taken to be the outcome, the verbal consensus. If, however, as is more likely in most parliaments, there is no verbal agreement, the chair may call for a ballot. The consensors draw up a final (short) list of options, normally on complex issues from four to six of them; next, each of the various parties are asked to confirm that their particular proposal has been included in this draft ballot, either verbatim or in composite; and then all concerned may cast their preferences on the various options listed.

\section{2. The MBC vote and count}

The MBC works like this. In a ballot on, say, five options:

if a voter casts only a $1^{\text {st }}$ preference, his favourite gets just 1 point;

if another casts two preferences, then her favourite gets 2 points and her second choice gets 1 point;

if her colleague casts three preferences, then his favourite gets 3 points, his second choice gets 2 and his third gets 1 ;

so best of all,

she who casts all five preferences gives her favourite 5 points, her second choice 4 , and so on.

In the count, the option with the widest level of support - and in those instances where every voter has cast a full ballot, this will be the option with the highest average preference is enacted. An average, of course, involves everyone voting, not just a majority of them.

On most subjects of contention, most people have preferences. If someone says something about one particular preference and nothing about any of the others, then he in effect casts 1$0-0-0-0$ points. She who casts three preferences uses 3-2-1-0-0 points. And those who cast all five exercise 5-4-3-2-1 points. In other words, he who abstains has no influence on the final outcome; she who submits a partial ballot has a partial influence; and those who submit a full list have a full influence.

15 The BC may also have been advocated by Ramon Llull in the $12^{\text {th }}$ century, but on this point, the science is unclear, [11]. 
In short, a person's $x^{\text {th }}$ preference always gets one more point than his $(x+1)^{\text {th }}$ preference, regardless of whether or not he/she has cast that $(x+1)^{\text {th }}$ preference. The difference is always one point; there is no especial weighting.

\subsection{The psychology of the MBC}

In an MBC, then, no one votes 'against' any body or any thing; nobody votes 'no'. Instead, albeit with varying degrees of enthusiasm, voters vote only 'for'. Given, then, that the MBC encourages all concerned to cast a full list of preferences, those who do so in effect recognise the aspirations of their fellow democrats. The methodology is inclusive.

At the same time, any protagonists know that success depends, partly on a good number of high preferences and perhaps on a few middle ones as well but, ipso facto, on very few low ones. It is therefore worth their while to talk to their erstwhile (majoritarian) opponents, so to persuade them to cast not a $5^{\text {th }}$ preference, but a $4^{\text {th }}$ or even higher preference.

Thus, both for the voters and for the protagonists, the MBC encourages dialogue, mutual respect, and full participation in the entire democratic process, both the debate and the vote. It is, indeed, inclusive.

As implied above, on those occasions when all the voters cast full ballots, the outcome will be, in effect, the option with the highest average preference. Thus, with an $\mathrm{MBC}$, the words 'majority' and 'minority' become obsolescent. To quote Nelson Mandela on 26.3.1999, on his retirement at the final sitting of South Africa's first democratically elected parliament, "... out of any debate... there should be no winners or losers." With an MBC, those two words do indeed become at least obsolescent: nobody wins everything but (almost) everybody wins something.

\section{4. The $M B C$ analysis}

Whenever an electorate casts its preferences in an $\mathrm{MBC}$, and on those occasions when many of those concerned submit full ballots, at least one option will get a final points total which is above the mean, others below. A number of scenarios are possible:

(a) if the most popular option gets a very high score, then ipso facto, most if not all of the others will be way behind, and this winning option may be termed the (near) unanimous opinion;

(b) if the most-liked option is not so far ahead, then, depending on its level of support (see below), maybe 'consensus' or 'best possible compromise' would be a better description;

(c) if two leading options are much more popular than the others but, as it were, neck and neck to each other, the consensors may decide to form a composite of the two.

If instead of one of the above three outcomes,

(d)(i) the winning option is only just above the mean, then obviously most or all the other options are also close thereto, in which case there is no consensus and the debate should be resumed; or maybe

(d)(ii) there is a cluster of a few options which are distinctly more popular than the others, in which case any future discussions could concentrate on themes covered by this cluster. 
One other scenario is worth a mention:

(e) when seeking a social ranking - a prioritisation or a short $\operatorname{list}^{16}$ - the consensors may wish to examine the results in some detail; if the object of the exercise is to identify a short list of, say, six options, and if the outcome shows that there is a cluster of seven options all distinctly more popular than the $8^{\text {th }}$ and lower options, then they may decide to present the outcome as a short list of not six but seven options.

To facilitate the consensors in their deliberations, and to make the whole process more transparent, each option is given a consensus coefficient; [12]. This is defined as:

the option's total number of points received

the maximum number of points that could have been achieved

It varies from a score of 1.0, which is very good, to zero, terrible. In a hypothetical five-option ballot on options $\boldsymbol{A}, \boldsymbol{B}, \boldsymbol{C}, \boldsymbol{D}$ and $\boldsymbol{E}$, with 100 voters submitting a full ballot, if option $\boldsymbol{D}$, say, gets 100 per cent first preferences, then $\boldsymbol{D}$ 's score will be $100 \mathrm{x} 5$, the maximum, and its consensus coefficient will be 1.0. If option $\boldsymbol{B}$ gets everybody's fifth preference, then its score will be $100 \mathrm{x} 1$, and its consensus coefficient 0.2 . In this scenario, therefore, the mean score is 0.6 .

Prior to the debate, a minimum consensus coefficient required for an option to then be enacted must be agreed to (in, say, standing orders).

\section{MAJORITARIAN AND NON-MAJORITARIAN FORMS OF GOVERNANCE}

For as long as people believe not only in the right of a majority to rule, but also in the notion that a majority opinion can be identified in a majority vote, parliaments and in some instances entire societies may tend to divide into two roughly equal halves; in many an elected chamber, the bigger 'half' wins all the power and forms the government while the smaller, the opposition, is left with none.

In the wake of the 2010 UK general election, with no one party gaining a majority of the seats in parliament, the parties involved chose to form a majority coalition government. But because so few parties are represented in Westminster, there were only three likely possibilities: the Tories and the Lib-Dems, Labour and the Lib-Dems, or a grand coalition of Tories and Labour. The maths, then, were fairly simple, and a deal was done in just five days.

Germany has a two-tier electoral system - multi-member proportional, MMP - while Poland has a PR-list system, and both countries tend to have two large parties and two or three small ones. The maths, therefore, are a little more complex, and in Germany in 2013, there were four realistic possibilities, if but in theory:

(i) and (ii) the Christian Democratic Union/Christian Social Union, CDU/CSU, (with 255

16 In an MBC of $n$ options, where $n \leq 10$, the voters may be asked to list a maximum of all of them. If the number of options, $N$, is such that $N>10$, then the voters may be asked to list a maximum of just $n$, with a recommended value of $n=6$. 
and 56 seats), with either the Left (64) or the Alliance 90/The Greens (63); the Social-democratic Party, SPD, (193), with both of the smaller parties despite their differences - or a grand coalition of the CDU/CSU plus SPD. ${ }^{17}$

Sometimes, then, as in 2009, the largest party joins forces with one of the smaller ones, and gives the latter a few ministerial seats; but by what right does a small party like the Free Democratic Party, FDP, in Germany, or the Polish People's Party, PSL, in Poland, get into government while a larger party, the German SPD or Polish Law and Justice Party, Pis, does not?

Ireland also has a PR electoral system - proportional representation, single transferable vote, PR-STV - and, therefore, four or five parties in parliament. Here too, a large party usually has to rely on a smaller party, or perhaps on an independent or two. Indeed, in February 1982, when the balance of power was delicately hung, Tony Gregory $\mathrm{TD}^{18}{ }^{18}$ an independent member of the Dáil, in return for a massive cash injection into his constituency, was the 'king maker'. Again, a question arises: is it right that one very small party, or even just one individual, may have such disproportionate power? ${ }^{19}$

In India, which uses first-past-the-post, FPP, the situation is definitely more complex. In 2009, the United Progressive Alliance, itself a coalition of eleven parties, won 262 seats; the National Democratic Alliance, a group of eight parties (two of which have their origins in the Janata Party), won 159; the Third Front, which also has 12 parties (a further two of which are Janata based) gained 79; the Fourth Front has a mere four parties (with only one Janata), and they got 27 seats; and a further seven parties won one seat each, as did nine independents. Given that parties often change their allegiances, both before and after elections, the possibilities for forming a majority coalition government become almost unlimited.

So too in other multi-party states, reliance on such a frail 'right' can but weaken democracy. In the Democratic Republic of the Congo, for example, in 2006, the 500 parliamentary seats were shared by one party with 22 per cent of the seats; one with 13 per cent; one with seven; two with five; one with three; six with about two; and a dozen or so with one; in addition, there were another dozen parties with less than one per cent and just two seats each, over a score of parties with less than half of one per cent with but one seat each, and 63 independents. In such circumstances, the process of forming a majority government is not unlike a lottery.

\section{1. Other Variations - the no-party or one-party state}

The word 'democracy' is sometimes used with abandon. In the Democratic Republic of North Korea, for example, voters don't vote. In China, which calls itself a 'consultative democracy', only some voters vote: "The combination of lawlessness and economic mismanagement from 1949 onwards... were the driving factors behind the introduction of

\footnotetext{
17 In 2005, when the two big parties were more finely balanced - CDU/CSU 226, SPD 222 - there were seven possible majority coalitions: either one big party plus any two of the three, or a coalition of the two big ones.

18 TD, Teachtaí Dála, member of the Irish parliament, Dáil Éireann.

19 Fianna Fáil, (FF) had 81 seats; Fine Gael 63; Labour 15; the Workers' Party 3; and there were 4 independents. FF formed a majority coalition with the help of the 3 plus 2 independents, one of whom was the said Mr. Gregory.
} 
elections after 1978. This at least gave governance in villages some semblance of legitimacy and popular support." [13]. The townsfolk must wait a little longer.

Now in theory, a no-party or one-party state could be democratic. One highly unlikely but nevertheless possible outcome of a UK general election could be a parliament in which every MP was an independent. A no-party state, then, is unlikely, but a one-party state nearly materialised in 1931, when the UK Conservative Party won over 75 per cent of the seats in parliament, admittedly, with just 55 per cent of the vote; in Lesotho, (FPP), in 1992, one party with 75 per cent of the vote got all 100 per cent of the seats - a democratic one-party state?

To-day, many African countries have adopted a majoritarian form of governance, but it was not always so. As Nelson Mandela observed "Majority rule was a foreign notion." [14]. Was it wise, it may be asked in retrospect, to bring such an adversarial political structure to a continent accustomed to other ways of decision-making? In particular, as noted above, to Rwanda?

Little wonder, then, that on gaining independence, some countries sought a different polity, and many of them adopted a one-party state. While a very bad example was in the Central Africa Republic under Jean-Bédel Bokassa, a good instance came from Tanzania, which initially had a very democratic one-party system. The first President, Julius Nyerere, described African democracy in these words:

"The elders sit under the big tree and talk until they agree. It is true that this 'pure' democracy - the totally unorganised 'talking until you agree' - can no longer be adequate; it is too clums [But that] does not necessarily imply the need to organise an opposition group as part of the system." [15]. Another story relates to Uganda where President Yoweri Museveni actually banned political parties because, "as soon as they were introduced, they became sectarian, based on ethnicity and religion." [16]. He has a point. He stopped a war.

Another example of a no-party state was the USA, which also started along non-partisan lines. "The alternate domination of one faction over another... has perpetrated the most horrid enormities [and] is itself a frightful despotism," was how George Washington described the English two-party system of governance in his farewell address of 1796 and, at the time, this view was shared by many in the New World.

Alas, while the founding fathers actually invented a formula of proportional representation - Thomas Jefferson wanted divisors while Alexander Hamilton preferred quotas - they also devised an inclusive presidential electoral system: the winner became the President and the runner-up was his Vice. What they did not do, however, was change the decision-making process, the two-option vote. It was, and it still is, an idée fixe.

Duverger's Law - 'the simple majority single-ballot system favours the two-party system' - determines how many parties there will be in the parliament; the use of majority voting, however, is the main catalyst of that very English (and very unAfrican) concept, or even oxymoron: the loyal opposition.

\section{2. A two-party or multi-party Polity}

Just as many western democracies have different electoral systems, everything from the inaccurate FPP to the rather more inclusive PR-STV - (yet all of these systems are called democratic) - so too there are many systems of government and many of these are also given this adjective.

Canada, which uses FPP and is therefore a two party state, sometimes relies on a minority administration. Other Anglo-Saxon democracies tend to have single-party majority governments, but in the UK (FPP), the prospects of any one party gaining 50 per cent of the seats is becoming less and less likely. Meanwhile, in the US (FPP), governance becomes 
problematic if not dysfunctional if and when the House of Representatives is governed by one party while the situation is reversed in Congress.

France has TRS, which tends to produce two big parties and, as in England, these are often referred to as 'left' and 'right'; sometimes, therefore, the middle ground gets lost. For reasons unclear, many French people are totally unaware that, prior to the 1789 revolution, members of l'Académie des Sciences discussed decision-making, not least M Jean-Charles de Borda and Le Marquis de Condorcet. In 1784, they adopted the BC, albeit mainly as an electoral system, and it worked quite well. But then a new member came along to what was now l'Institute Français, and he changed it all back again to majority voting - an individual to whom reference has already been made, Napoleon Bonaparte, [17].

Countries with PR-list, like Denmark and Poland, have quite a few parties, and their governments are usually based on either minority administrations or majority coalitions. As already noted, Germany (MMP) usually has either a majority- or even a grand coalition.

\section{3. All-party power-sharing}

Another possibility is the all-party coalition, such as exists in Switzerland (whose electoral system is a multiple-choice version of PR-list), which also tends to have quite a few parties. This form of governance, a seven-member Federal Council chosen originally on a 2:2:2:1 'magic formula' of members from the four largest parties, was adopted in 1959; while the fortunes of various parties may change at general elections - the ratio is currently 2:2:1:1:1 and five parties are involved - the 'magic' is holding, for the moment at least.

In some jurisdictions, power-sharing exists as part of a post-conflict settlement. Sometimes, the administration is chosen via a recognised procedure: Northern Ireland chooses its incoming Executive via a d'Hondt interpretation of the recent election, with the top parties appointing ministers in a process described as 'cherry picking'; in Bosnia, a three-person presidency is elected on an ethno-religious basis ${ }^{20}$ - one for each group; while in Lebanon, certain positions are reserved for those of particular confessional beliefs: the president was a Maronite, the prime minister a Sunni [and] the speaker a Shia. In effect, then, nearly all of these formulas have tended to perpetuate the very divisions they were meant to overcome. The Belfast Agreement, for example, has in effect "rewarded those who pursue strategic sectarian ethno-religious calculations - as is evident from... the politics of Executive formation." [18]

Better that, it might be argued, than a process in which there are no formulas at all, in which reliance is placed on a purely verbal process. Hence, as noted in the introduction, the 249 days of negotiations spent in Iraq. Hence, too, the need for external mediation, as was the case in Kenya in the wake of the 2008 post-electoral violence, where the negotiations took 70 days.

If, however, it is right for such plural societies to have all-party power-sharing after a crisis, would it not have been even more right to have had such an administration beforehand? The latest country for which this question is so painfully relevant is, of course, Ukraine. In other words, maybe every country should have a GNU, an all-party coalition, as of right; and maybe the best way of structuring such a form of governance would be for the respective parliament to use a proportional electoral system which was ethno-colour blind.

If, furthermore, the non-majoritarian $\mathrm{MBC}$ were to be adopted as the accepted norm of decision-making for those occasions when the debate in question was controversial and/or

$20 \quad$ The three communities - Bosniaks, Bosnian Croats and Bosnian Serbs - all Slavs, follow mainly Muslim, Catholic and Orthodox religions respectively. 
complex, there would no longer be any 'justification' for majority rule and therefore for single-party government or only majority- or grand coalitions. Democracy, after all, is for everybody. A more inclusive polity would be necessary: so not only should parliament represent the people, all of them, but likewise the government should represent the parliament, all of it.

\section{ELECTING A GNU}

The question, then, is this: in a normal society as well as in any post-conflict scenario, how can a multi-party parliament elect a proportional government in which each individual minister undertakes a specific responsibility? The answer, the appropriate voting methodology, is a matrix vote, [19]. It is another Borda procedure, and an example of a ballot paper for use in the Polish Sejm is shown in Table 1. Members of the newly elected parliament would cast their preferences, not only for those whom they wanted to see in government, but also for the ministerial post in which they wished each of their nominees to serve - it is therefore a tabular ballot paper, and hence the word 'matrix'.

Table 1. A Council of Ministers matrix vote ballot paper.

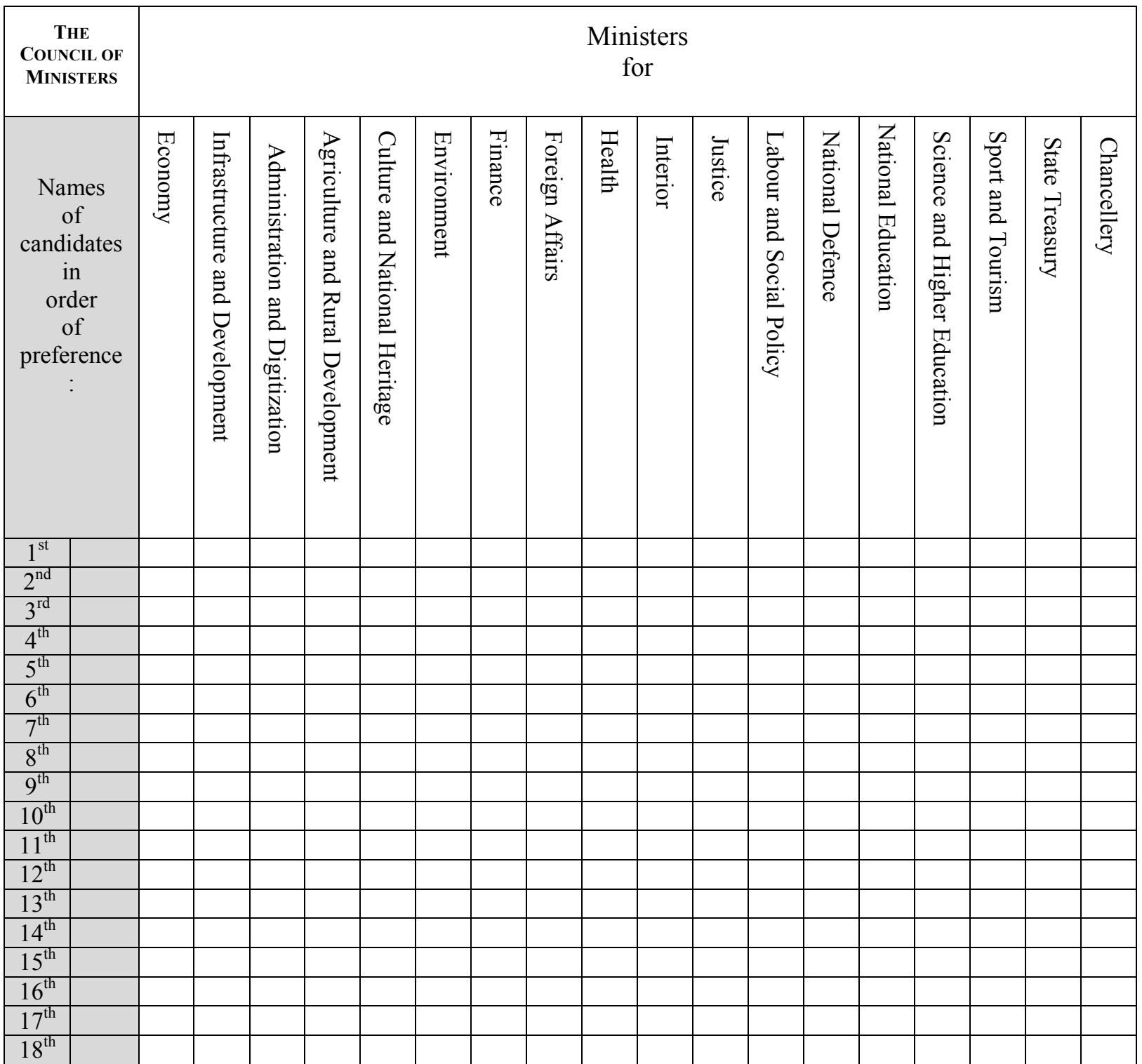


Every member of the Bundestag would first identify the 18 individuals he/she wanted to be in cabinet and then list these 18 names in order of preference, in the left-hand part of the ballot paper (here shown in tint). As in any Borda methodology, a ballot of only one preference can be valid, but a full vote would consist of 18 different names. The member could then indicate the portfolio in which he/she wished each of these nominees to serve by ticking the appropriate column in the matrix (here shown untinted). Table 2.

A hypothetical example of how a very hypothetical member might vote is shown in

Table 2. A member's matrix vote ballot paper.

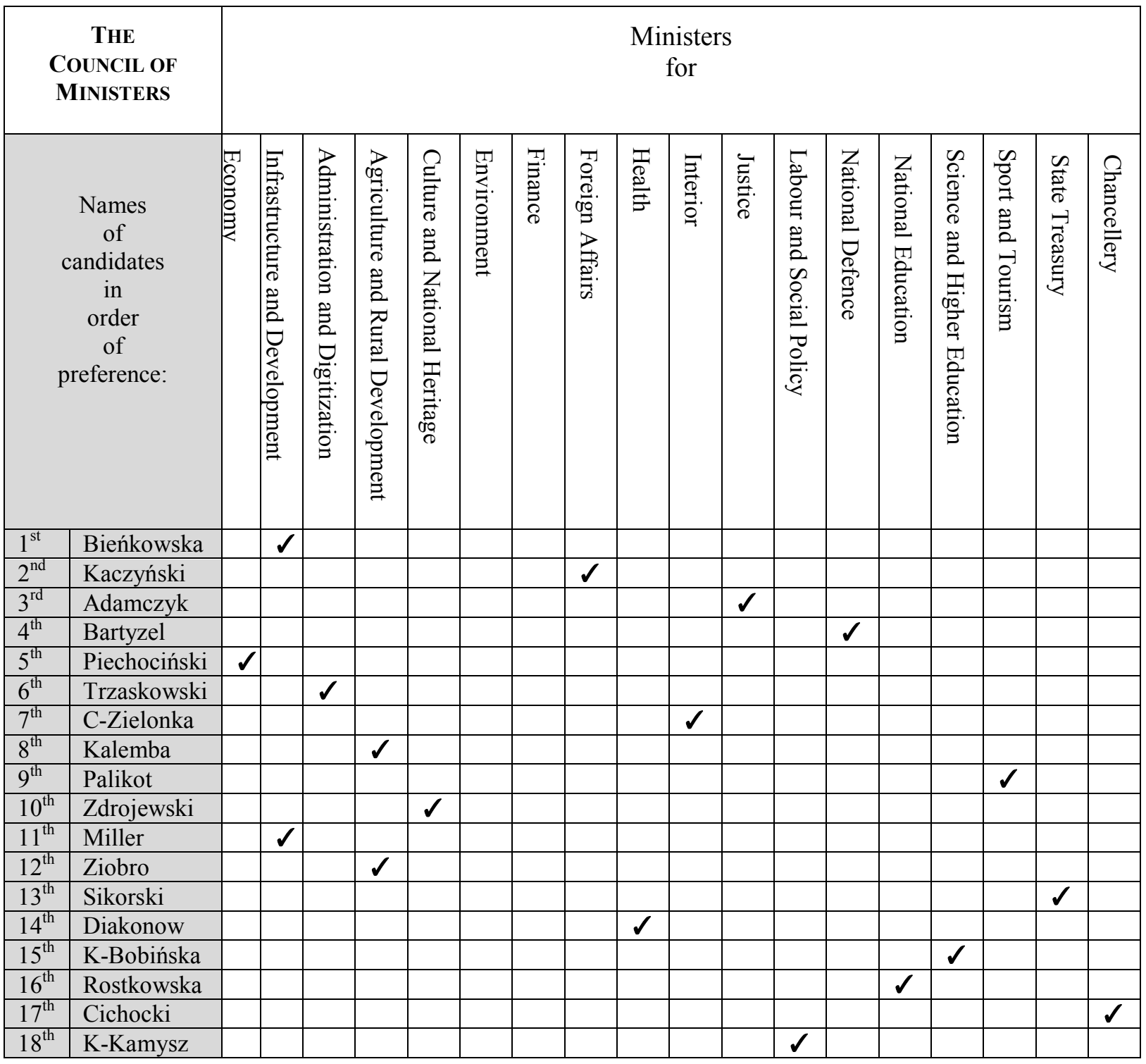

The voter, let's say a male, casts a full ballot, so his first preference gets 18 points, his second gets 17, and so on. He gives his first preference to Bieńkowska, who thus gets 18 points towards her possible appointment as Minister for Infrastructure and Development. 
Another member of parliament, Kaczyński, gets this voter's second preference, so Kaczyński gets 17 points for Foreign Affairs; and so on.

The count consists of two analyses. Firstly, there is a quota Borda system, QBS, analysis of the preferences cast to identify the 18 most popular members, i.e., to see who are to be in cabinet; and because QBS is a proportional form of the MBC, the outcome is (almost) bound to be an all-party, power-sharing, coalition cabinet, a GNU. The second count consists of an MBC analysis of the points awarded in the matrix, to see who should serve in which department. Thus, at best, the result will be such that, individually, each minister is the member of the Sejm best suited to that particular portfolio, while collectively, each party is represented in fair and proportional due.

The outcome of a matrix vote, the collective will of the Sejm, would be presented in the form of another matrix, an even more hypothetical example of which, with totally fictitious first names, is shown in Table 3; obviously, in real life, the points scores would be much higher totals. It should be pointed out that any one minister's MBC total may be more than the score she received for her ministry, because of points she received for other portfolios. Furthermore, the sum of the totals in the bottom row is obviously greater than the sum of the totals in the right-hand column, because of all the points awarded to candidates who did not get elected.

Table 3. The collective will.

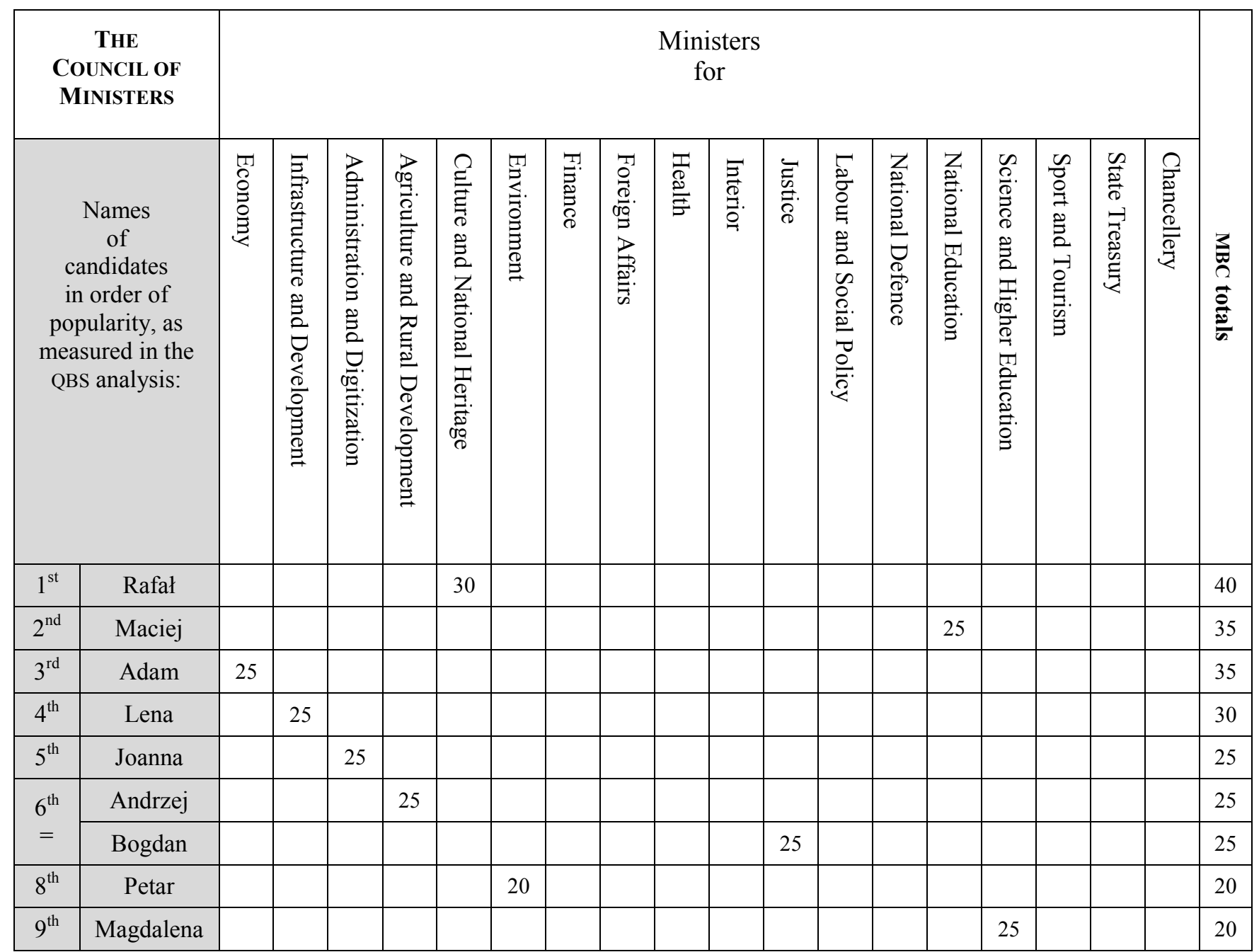




\begin{tabular}{|c|c|c|c|c|c|c|c|c|c|c|c|c|c|c|c|c|c|c|c|c|}
\hline $10^{\text {th }}$ & Maja & & & & & & & 20 & & & & & & & & & & 20 \\
\hline $11^{\text {th }}$ & Elżbieta & & & & & & & 20 & & & & & & & & & & & & 20 \\
\hline $12^{\text {th }}$ & Tomasz & & & & & & & & & & 20 & & & & & & & & & 15 \\
\hline $13^{\text {th }}$ & Agnieszka & & & & & & & & 15 & & & & & & & & & & & 15 \\
\hline $14^{\text {th }}$ & Stanisław & & & & & & & & & & & 15 & & & & & & & 15 \\
\hline $15^{\text {th }}$ & Aleksandra & & & & & & & & & & & & 10 & & & & & & 10 \\
\hline $16^{\text {th }}$ & Borys & & & & & & & & & & & & & & & & 10 & & 10 \\
\hline $17^{\text {th }}$ & Alicja & & & & & & & & & & & & & & & & & 10 & 10 \\
\hline $18^{\text {th }}$ & Luiza \\
\hline $\begin{array}{c}\text { Total number of } \\
\text { points cast per } \\
\text { portfolio: }\end{array}$ & 50 & 50 & 45 & 45 & 40 & 40 & 30 & 35 & 20 & 25 & 30 & 40 & 20 & 20 & 25 & 30 & 20 & 15 & \\
\hline
\end{tabular}

The process is thus bound to be transparent, and the outcome is bound to be proportional and fair. It should also be pointed out, of course, that while the matrix vote could indeed be used by the entire Sejm to elect a GNU, it could also be used by the parliamentary members of the relevant parties to elect a grand coalition, or for that matter by any one party to elect its national executive. The methodology also has potential applications in civic society, where it can be (and has been) used to elect executive committees at AGMs.

\subsection{The psychology of the matrix vote}

Consider a parliament in which there are five parties, $\boldsymbol{V}, \boldsymbol{W}, \boldsymbol{X}, \boldsymbol{Y}$ and $\boldsymbol{Z}$, with respectively $50,30,10,5$ and 5 per cent of the seats. In any cabinet of 18 ministers, $\boldsymbol{V}$ and $\boldsymbol{W}$ can expect to win roughly nine and five seats, while each of the other three parties get two or just the one seat. Now, as stated above, the MBC encourages the voter to submit a full ballot. In this instance, every member would be asked to cast (up to) 18 names.

Accordingly, any $\boldsymbol{V}$ party member would be well advised to use her high preferences for nine (or maybe ten) preferences for her party colleagues, and any lower preferences for those MPs of the other parties with whom she considers her $\boldsymbol{V}$ party colleagues can best co-operate. In effect, therefore, the matrix vote encourages inter-party dialogue and cross-party voting; two essential ingredients, it is argued, of a power-sharing administration.

\section{2. The Practicalities}

Such a government, and such a parliament, would best be able to work if, in taking decision on contentious and/or complex issues, use is made of the MBC. In which case, it would be advisable to allow the MPs a free vote. ${ }^{21}$

\footnotetext{
21 The whipped vote is predicated on a majority vote within a divided, government-versus-opposition, parliament. In a five-option $\mathrm{MBC}$, however, where there are 120 different ways of submitting a full ballot, the system of whipped votes would naturally become obsolescent. When choosing 18 ministers in order of
} 
In any subsequent election, if the fortunes of, let us say, Party $\boldsymbol{W}$ changed a little, if it now won not 30 but just 20 per cent of the seats, then it could expect to win not five but about three ministerial positions. In consensus politics, rather than suffer the dramatic changes so common to adversarial structures, a jurisdiction's politics would more peacefully evolve.

In other words, a combination of the matrix vote to elect the government, and then the MBC in any subsequent decision-making, both within government and in parliament, would allow for an effective form of rule, for a more inclusive form of governance, and an altogether better parliamentary milieu.

\section{CONCLUSION}

As noted above, the only country to advance towards a form of all-party government without first suffering a violent crisis was Switzerland. Most others - Bosnia, Kenya, Lebanon, Northern Ireland, etc., and now Ukraine - have been forced to adopt a form of power-sharing as a way of bringing together the otherwise antagonistic elements of their divided societies. So maybe the world would be a better place if first it were accepted that there was no such thing as the right of a majority to rule by majority vote; secondly that, in its stead, a more inclusive polity based on power-sharing was a democratic right; and thirdly, that all democratic structures - not just the election of parliament but also the (s)election of government - should be accurate, transparent, and ethno-colour blind.

\section{ACKNOWLEDGEMENTS}

The BC was first advocated by Nicholas Cusanus in 1435, but it was Jean-Charles de Borda in 1784 who did most of the initial mathematical analysis. QBS was devised by the late Sir Michael Dummett in 1984. And the matrix vote was invented by the author in 1978.

\section{BIOGRAPHY}

Peter Emerson first gained a degree equivalent and then served in the British navy in submarines, mainly in the Far East. Having seen much of the poverty which (still) haunts this world, however, he resigned his commission and worked, instead, as a volunteer teacher in a school for the poor in Kenya. Four years later, in 1975, he moved to Belfast, where he soon became a peace activist, promoting inclusive voting procedures and bringing the two sides together in consensus experiments.

As a direct result of this work, he campaigned against all forms of violence, including the nuclear bomb. Thus, in 1984, he chose to visit the Soviet Union. Four years later, with perestroika well underway, he published articles on democratisation in Moscow News and Novy Mir (Hовый Mup).

In 1997, he and a few colleagues set up the de Borda Institute. As the director, he has lectured on power-sharing in Europe, Africa, the Americas, and most recently China. His latest work is Defining Democracy (Springer, 2012). He speaks Russian, some Serbo-Croat and Swahili, and is now learning Mandarin Chinese. 


\section{References}

[1] Lijphart Arend, 1999. Patterns of Democracy, Government Forms and Performance in Thirty-Six Countries. $2^{\text {nd }}$ edition. New Haven and London: Yale University Press. 6

[2] Deutscher Isaac, 1982. Stalin. London: Pelican. 71.

[3] Emerson Peter, 2012. Defining Democracy. Voting Procedures in Decision-Making, Elections and Governance. Heidelberg and Berlin: Springer. 143-50.

[4] Schram Stuart, 1969. The Political Thought of Mao Tse-tung. New York, Washington and London: Frederick A Praeger. 313.

[5] Prunier Gérard, 1995. The Rwanda Crisis. London: C Hurst and Co.. 183.

[6] Bogdanor Vernon, 1981. The People and the Party System. Cambridge: Cambridge University Press. 92.

[7] Emerson Peter, 2012. Defining Democracy. Voting Procedures in Decision-Making, Elections and Governance. Heidelberg and Berlin: Springer. 163-165.

[8] Emerson Peter, (a). The original Borda count and partial voting. Social Choice and Welfare 40(2) (2013) 353-358.

[9] Sigmund Paul, 1963. Nicholas of Cusa and Medieval Political Thought. Cambridge, Massachusetts: Harvard University Press. 212.

[10] Saari Donald, 2008, Disposing Dictators, Demystifying Voting Paradoxes. Social Choice Analysis. Cambridge: Cambridge University Press. 95.

[11] McLean Iain, Urken Arnold, 1995. Classics of Social Choice, Michigan: Ann Arbor University of Michigan Press. 16-19.

[12] Emerson Peter, 2007. Designing an All-Inclusive Democracy. Consensual Voting Procedures for use in Parliaments, Councils and Committees. Heidelberg and Berlin: Springer. 17.

[13] Brown Kerry, 2011. Ballot Box China. London: Zed books. 18-19.

[14] Mandela Nelson, 1994. Long Walk to Freedom. London: Little Brown and Company. 25.

[15] Nyerere Julius, 1961. One-party Rule. In The Ideologies of the Developing Nations, pp. 196-211. Ed. Sigmund, Paul. New York, Washington and London: Frederick A Praeger. 197-8.

[16] Musevei Yoweri, 1997. Sowing the Mustard Seed. The Struggle for Freedom and Democracy in Uganda. London: Macmiillan. 200. 
[17] Black Duncan, 1958. The Theory of Committees and Elections. Cambridge: Cambridge University Press. 180.

[18] Taylor Rupert, 2009. The Injustice of Consociationalism. In Consociational Theory. Ed. Taylor, Rupert. Abingdon and New York: Routledge. 320.

[19] Peter Emerson, International Letters of Social and Humanistic Sciences 10(2) (2014) 132-55. 